\title{
Christian Invocations in the Papyri: a Supplement
}

I

our article "Christian Invocations in the Papyri " $\left({ }^{1}\right)$ we noted in the introduction that we did not claim to have collected all invocation formulas occurring in Coptic sources, nor most references to Greek inscriptions from Egypt. Though even now we cannot claim to have collected the pertinent data in both fields exhaustively, enough material has been assembled to warrant a short supplement to the list of formulas and their attestations given in that article. The dispersed publications and poor indexing of this material makes its assemblage difficult and completeness elusive. There is indeed a great need of a Coptic Sammelbuch. Such a work would save scholars much trouble, and it is a pleasure to see that such a project has been announced by M. Krause $\left({ }^{2}\right)$. One may hope that this will also take account of the many Coptic inscriptions on stelae etc. As regards Greek inscriptions, attention has been limited to the study of Egypt proper $\left({ }^{3}\right)$, thus excluding the Greek inscriptions from Nubia $\left({ }^{4}\right)$, though these too contain invocation formulas.

(1) See $C d^{\prime} E 56$ (1981), 112-133. We gladly take this opportunity to correct a few errors in this article. P. 120, form. 2B : P. Lond. II 483 comes from the Apollinopolite Heptakomias (information kindly provided by J. Gascou [Paris]), P. Paris 21 comes from the Thinite, SB I 5112 comes from the Apollinopolite Ano; n. 2: read for átiov, a vias; n. 3 : read for "Cf. n. 13 ", "Cf. preceding note". P. 121: read for "5112, 5114 ", "5112-5114 ". P. 125 : Of the texts listed under formulas 2B, 2D and 2E listed on this page none are in fact $\mathbf{2 D}$. The following are formula $\mathbf{2 B}: P$. Wïrzb. 19 (Hermopolite ; cf. now Anagennesis 1 [1981] 98: 622 ${ }^{\text {D) }}$ and P. Edfu I 4 (Apollinopolite). The remainder are all formula $2 \mathbf{E}$. Ad ST 97 , listed on this page, it should be remarked that the editor's restorations are not likely; the restoration at the end of line 1 belongs at the start of line 2. P. 126, form. 2G : BM Or. 6204 should have been listed on p. 123, form. 2G ; form 2? : SPP X 169 (cf. for this text p. 130) should have been listed on p. 124, form 2 ?. For the papyrus dealt with in our appendix, pp. 131-133 (CPR I $30 \mathrm{fr} . \mathrm{i}=$ M. Chrest. 290), see the forthcoming new edition of the text in CdE 57 (1982).

(2) See M. Krause, Nubia. Récentes recherches. Actes du colloque nubiologique internat. au Musée national de Varsovie, 19-22 juin 1972 (Warszawa 1975), p. 76 n. 8.

(3) See E. Bernarnd, ZPE 26 (1977) 95-117.

(4) Cf. J. Kubinska. FARAS, IV : Inscriptions grecques chréfiennes (Warszawa 1974) ; M. G. Tibiletti Bruno, Iscrizioni Nubiane (Pavia 1964 ; = Istituto Lombardo. 
In this supplement already known formulas are indicated by the designations used in our preceding article, i.e. without repeating the full formula. Furthermore, a few new formulas from Greek and Coptic sources have been discovered which are given here in full with a designation which follows the order of the earlier designations.

\section{a. KNOWN INVOCATIONS:}

2G or (less likely) $2 F$

Babylon? VIII, 14th ind. Ryl 121 (2)

This papyrus also contains a text written in Hermopolis. If the document with the invocation was written in Babylon - as the heading of the contract would suggest - it would present us with an aberration from normal practice in showing a Holy Trinity invocation in use in Lower Egypt after A.D. 610 ; but cf. SPP X 169 which seems to present also part of a Trinity invocation in a Fayumic papyrus from A.D. 763 (cf. Cd'E 56 [1981] 130).

2J Jeme VII/VIII, Pharmuthi 7, Cd'E 41 (1966) 215; in Coptic (Thebes) 2nd ind.

$\begin{array}{ll}? & \text { ST } 60 \text {; in Coptic ; omits the Son } \\ ? & \text { ST } 107 \text {; in Coptic } \\ ? & \text { ST } 214 \text { (mostly lost) ? In Coptic } \\ ? & \text { ST } 340 \text { (partly lost ; already lis- } \\ & \text { ted Cd'E } 56 \text { [1981] } 126 \text { as for- } \\ & \text { mula } 2 \text { ?) } \\ ? & \text { ST } 405 \text { (2); in Coptic } \\ ? & \text { ST } 412 \text {; in Coptic ; om. the } \\ ? & \text { Father } \\ ? & \text { ST } 429 \text {; in Coptic } \\ ? & \text { Hall pl. LVII no. } 5 \text {; in Coptic } \\ ? & \text { Hall pl. LXIX no. } 2 \text {; in Coptic } \\ ? & \text { Hall pl. LXX no. } 1 \text {; in Coptic } \\ & \text { Hall pl. LXXIII no. } 1 \text {; in Cop- } \\ & \text { tic }\end{array}$

Accad. d. Scienze e lettere. Rendiconti, Cl. d. Lett., 97 [1963] 491 ff.) ; J. F. Oates, JEA 49 (1963) 161-171 ; J. W. B. Barns, Kush 2 (1954) 26-32 (the inscriptions published by Barns and Oates never entered $S B$ or $S E G)$. 
(2J) (Jeme) ?

$?$

ca. 600

?

$?$

?

?

?

VII

?

Nubia ?

2L Jeme ?

(Thebes)
Hall pl. LXXV no. 1 ; in Coptic

Hall pl. LXXVI no. 1 ; in Coptic (1)

CO 135 (Till, 177, s.n. Philotheos, son of Zebedaios); in Coptic

CO 138 ; in Coptic

CO 140 ; in Coptic

KOW 107 ; in Coptic

KOW $188=$ ST 225 ; in Coptic KOW $219=$ ST 295 ; in Coptic (partly lost)

Ep 92 ; in Coptic

Christianskij Vostok 1 (1912) $207=$ Kossack, Lehrbuch $d$. Koptischen 340, no. 128; in Coptic

Sb. Akad. Berlin, Phil.-Hist. Kl. 1913. 8, 54. 1

CO 393; adds an extra $\varepsilon$ Tor\& \& bef. NBouoorcioc

b. New Invocations :

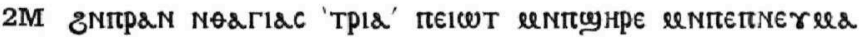

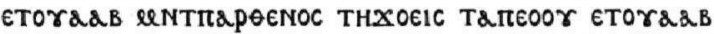 \\ Provenance? ? \\ Sphinx $10(1906) 2\left({ }^{2}\right)$}

(1) For Hall, App. no. 17 (p. 145) cf. Hall, App. 14 (p. 142) ; invocation not necessarily to be restored.

(2) Translation: "In the name of the Holy Trinity, the Father and the Son and the Holy Ghost and the Virgin, the Lady who enjoys holy glory ". After we closed the Ms. of this article Dr. L. S. B. MacCoull kindly informed us that she will republish this papyrus in Studi in Onore di Ugo Monneret de Villard (Rome) with a commentary. The papyrus is kept in the Graeco-Roman Museum at Alexandria as inv. no.647. Dr. MacCoull reads the invocation as follows: $+[8] \operatorname{le} P \&[N$ TH]

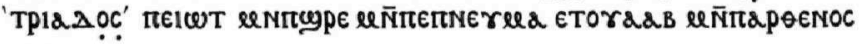




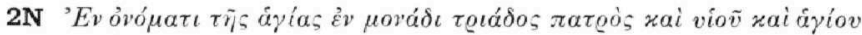
$\pi v \varepsilon v ́ \mu \alpha \tau o s$

Great Oasis ?

$$
\text { ASAE } 9 \text { (1908) } 183=\text { Lef. } 357.2
$$

(inscription)

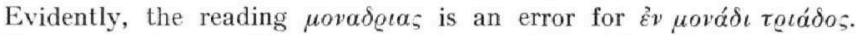
This is our formula $2 \mathrm{~F}$ lacking the epithets $\zeta$ (1) the Holy Trinity.

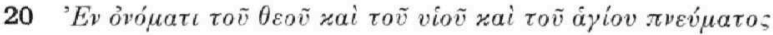

Jeme VIII KOW 103

? Hall pl. XXXI.3 (partly lost, our rest.)

Evidently, this formula is a cross-combination of the Arabic Bismillah (cf. Cd'E 56 [1981] 113 n. 2) and our formula 2J.

Lastly Ryl 408 $8^{\mathrm{r}}$ should be mentioned. This document reads (as far as preserved) :

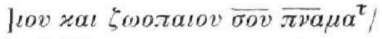

]

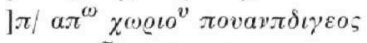

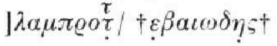

From a photo kindly provided by the John Rylands Library we can testify to the correctness of the editor's readings. The top of the document is not preserved, i.e. there is no upper margin. Nevertheless, our impression is that we are dealing here with the heading of a document starting with an invocation, followed by a (partly lost) date to the month, day and the indiction. If so, we must assume a serious scribal

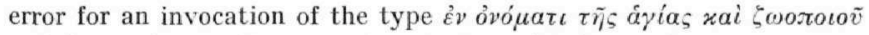

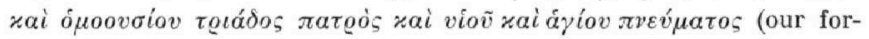
mula $2 \mathbf{F}$ ), as there is no invocation known in which only the Holy Ghost,

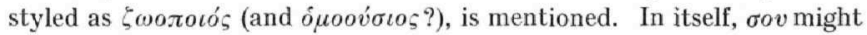
be taken as Nomen Sacrum for $\sigma(\tau \alpha v ́ g) o v$, but we know of no examples of the Cross being styled as לwazoıós.

New York

Amsterdam
Roger S. Bagnall

K. A. WORP

TÑ̈OH $\theta / /$ Tdeleoor coradB, i.e. "In the name of the Holy Trinity, the Father and the Son and the Holy Spirit, and the Virgin our protector, my (sic) holy mother and she thinks that the papyrus has a Fayumic provenance. 